\title{
Effects of seedling density on the growth of Corsican pine (Pinus nigra var. maritima Melv.), Scots pine (Pinus sylvestris L.) and Douglas-fir (Pseudotsuga menziesii Franco) in containers
}

\author{
Richard Jinks $^{\mathrm{a} *}$, Bill Mason ${ }^{\mathrm{b}}$ \\ ${ }^{a}$ Forestry Commission Research Agency, Alice Holt Lodge, Wrecclesham, \\ Farnham, Surrey, GU10 4LH, United Kingdom \\ ${ }^{b}$ Forestry Commission Research Agency, Northern Research Station, \\ Roslin, Midlothian, EH25 9SY, United Kingdom
}

(Received 20 May 1997; accepted 29 September 1997)

\begin{abstract}
Corsican pine, Scots pine and Douglas-fir seedlings were grown in containers at a constant volume at densities ranging from 100 to over 1000 plants $\mathrm{m}^{-2}$. Both shoot and root dry weight of each species decreased with increasing density, especially at densities greater than $500 \mathrm{~m}^{-2}$. In contrast, shoot height of Corsican and Scots pine increased at high densities, but the height of Douglas-fir was unaffected by density. Shoot height was not correlated with dry weight in Douglas-fir and Scots pine, and was negatively correlated in Corsican pine. Root collar diameter was positively correlated with seedling weight in all three species. Increasing the volume of tray cells only increased seedling size in Douglas-fir at densities lower than $400 \mathrm{~m}^{-2}$. Survival of outplanted Douglas-fir seedlings was reduced in plants grown at the highest density $\left(1550 \mathrm{~m}^{-2}\right)$. Height and diameter increments were greatest in plants raised at intermediate densities around $780 \mathrm{~m}^{-2}$. (@) Inra/Elsevier, Paris.)
\end{abstract}

Pinus nigra var. maritima / Pinus sylvestris / Pseudotsuga menziesii / containers / density

Résumé - Effets de la densité des semis sur la croissance du pin noir de Corse (Pinus nigra var. maritima Melv.), du pin sylvestre (Pinus sylvestris L.) et du sapin de Douglas (Pseudotsuga menziesii Franco) en conteneurs. Des semis de pin noir de Corse, pin sylvestre et sapin de Douglas ont été cultivés en conteneurs à volume constant, avec des densités variant de 100 jusqu' à plus de 1000 plantes $\mathrm{m}^{-2}$. Le poids sec des pousses et des racines a décru chez chaque espèce lorsque la densité se trouvait accrue, particulièrement dans le cas de densités supérieures à $500 \mathrm{~m}^{-2}$. Par contraste, la hauteur des pousses du pin noir de Corse et du pin sylvestre s'est accrue

\footnotetext{
* Correspondence and reprints

E-mail: r.jinks@ forestry.gov.uk
} 
avec les densités élevées, mais celle du sapin de Douglas n'a pas été changée par la densité. Il n'y a pas eu de corrélation entre la hauteur des pousses et le poids sec chez le sapin de Douglas et le pin sylvestre, mais on a observé une corrélation négative chez le pin noir de Corse. Le diamètre du collet a montré une corrélation positive avec le poids des plantes chez les trois espèces. L'augmentation du volume des compartiments des bacs n'a pas accru la taille des semis de sapin de Douglas que dans le cas de densités inférieures à $400 \mathrm{~m}^{-2}$. La survie des semis de sapin de Douglas repiqués était réduite chez les sujets cultivés à la densité la plus élevée (1550 $\mathrm{m}^{-2}$ ). Les plus grandes accroissements en hauteur et en diamètre ont été trouvés le plus élevé chez les plantes cultivées en utilisant des densités intermédiaires à peu près de 780 semis $\mathrm{m}^{-2}$. ( $\odot$ Inra/Elsevier, Paris.)

\section{Pinus nigra var. maritima / Pinus sylvestris / Pseudotsuga menziesii / conteneurs / densité}

\section{INTRODUCTION}

There is a wide range of cellular or modular tray systems available for raising tree seedlings and these are designed with features that favour seedling growth and are also efficient for nursery and outplanting operations. The size and arrangement of the cells in trays has an important influence on seedling size and must be matched to the species growth rate and the length of the production period. The growth of seedlings is affected by both cell volume and by the growing density imposed by the spacing of the cells in the trays. Generally, seedling size becomes larger when cell volume is increased while growing space is held constant $[2,6,7$, 15]. The greatest increase in size often occurs in response to changes in the volume of small cells since small cells restrict growth earlier than larger ones [6]. The dimensions (diameter and height) of the cells used to achieve a particular volume can also influence growth of shallow rooting species like white spruce (Picea glauca (Moench) Voss) where, at the same density, seedlings grew more in wider diameter cells [2].

Container density is considered to be as important a factor as cell volume in governing seedling growth [9]. There are, however, relatively few reports on the direct effects of seedling density on growth in the absence of confounding effects of cell volume. Comparisons of seedling growth in different sized containers are often difficult to interpret because an increase in cell volume is usually accompanied by an increase in the distance between cells. In tray systems where the cells are separated from each other, the effects of growing density are caused by competition for space and light between the shoots of neighbouring seedlings; competition for water and mineral nutrients only occurs in systems with permeable cell walls such as paper pots.

In general, the results of the few studies where container volume has been held constant show that seedlings grown at higher densities tend to grow taller but have lower stem diameters and dry weight than seedlings grown at wider spacing [ 1 , 14, 16]. However, species appear to differ in their responsiveness to changes in container density, particularly in terms of effects on shoot height. In Douglas-fir seedlings grown at four densities, shoot height was only slightly affected by density between 270 and 810 seedling $\mathrm{m}^{-2}$, but was increased by $40 \%$ at $1080 \mathrm{~m}^{-2}$ [16]. Spacings between 450 and 1808 seedlings $\mathrm{m}^{-2}$ had little effect on the height of loblolly pine seedlings. Longleaf pine, however, showed a much larger increase in both height and seedling dry weight than loblolly pine when grown in a larger vol- 
ume, wider-spaced container system [1]. Shoot height of white spruce increased by $60 \%$ as density was increased from 100 to $1100 \mathrm{~m}^{-2}$, while stem diameter and root weight all decreased [14].

In British nurseries, the height of seedlings of Corsican pine (Pinus nigra var. maritima Melv.) grown in containers is often uneven both within individual trays and across benches. Seedlings in the centre of benches are usually taller than those at the edges, suggesting that this species is particularly sensitive to seedling density. The aim of the first experiment was to test if height growth of Corsican pine is particularly responsive to growing density. Growth of Corsican pine at different densities was compared with Scots pine and Douglas-fir in the second and third experiments. The interaction between cell volume and growing density on the growth of Douglas-fir seedlings was investigated in the fourth experiment. Finally, the effects of container density on the growth and survival of Douglas-fir seedlings after outplanting was studied in the fifth experiment.

\section{MATERIALS AND METHODS}

Experiments 1 and 2 on Corsican and Scots pine were carried out at the Forestry Commission Research Station, Alice Holt Lodge, Farnham, Surrey (UK) (latitude $51^{\circ} 11^{\prime} \mathrm{N}$ ), while seedlings of coastal origin Douglas-fir in experiments 3 and 4 were raised at the Northern Research Station, Roslin, Midlothian (UK) (latitude $55^{\circ} 53^{\circ} \mathrm{N}$ ). All seedlings were grown in peat-based growing media and were fertilized by applications of liquid fertilizer during growth (table l).

\subsection{Experiment 1}

Corsican pine seeds (UK Forestry Commission identity number 87(40.32) Lot 10) were

Table I. The composition of the growing media and the fertilizer programme used to raise seedlings of Corsican pine, Scots pine and Douglas-fir.

\section{Corsican pine Douglas-fir}

Scots pine

Bulk ingredients (\%)

Sphagnum peat

Medium grade vermiculite

Base fertilizers $\left(\mathrm{kg} \mathrm{m}^{-3}\right)$

Osmocote (18-6-12) 2-3 months

Ammonium nitrate

Single superphosphate

Potassium nitrate

Magnesium limestone

Ground limestone

Fritted trace element WM253A

Liquid fertilizer $\left(\mathrm{mg} \mathrm{L}^{-1}\right)^{*}$

$\mathrm{N}$

$\mathrm{P}$

K
100

0

0

0.2

0.75

0.4

2.5

0

0.3
75

25

1.0

0

0

0

2.4

1.2

0.30

* Liquid fertilizers also contained trace elements. Feeding commenced after the first primary needles had appeared, approximately 6 weeks after sowing. 
sown in Lannen Ecopot (Lannen UK Ltd, Cambridge, UK) 308 trays (cell volume $53 \mathrm{~cm}^{-3}$ ) at four densities ranging from 1525 to about 200 seedlings $\mathrm{m}^{-2}$. This system was used because the cell walls are made from plastic laminated paper, which minimizes the lateral transfer of water, nutrients and roots between neighbouring cells. The cells in Ecopot trays were arranged in an hexagonal arrangement such that each cell was bounded by six neighbours and the four seedling densities were achieved by missing out selected cells in the trays. All cells were sown to give the highest density of 1525 plants $\mathrm{m}^{-2}$. Omitting to sow three alternate neighbours gave a density of 1030 plants $\mathrm{m}^{-2}$, and by leaving one or two empty cells between seedlings produced densities of 384 and 192 plants $\mathrm{m}^{-2}$ respectively. Each density treatment was replicated four times and trays were arranged in a randomized block design in an unheated polythene tunnel.

Two seeds were sown in each cell during March. Seed was then covered with a thin layer of grit. A sheet of white polythene was placed over the trays until about $10 \%$ of the seed had germinated, after germination seedlings were thinned to single plants per cell. Seedlings were grown on through the summer and seedling height and root collar diameter were assessed on 20 seedlings randomly selected from the centre of each plot in autumn after growth had ceased. Linear and quadratic effects on seedling growth were tested for by analysis of variance (ANOVA) using procedures in Genstat [13].

\subsection{Experiment 2}

Seedlings of both Corsican pine and Scots pine (identity numbers $87(4032)$ Lot 10 and 86(2009), respectively) were each grown at ten seedling densities ranging from just over 1000 to about $130 \mathrm{~m}^{-2}$ using a hexagonal arrangement of cells. Densities were obtained by either missing out one or more of the six immediate neighbours around seedlings or by having one or more empty cells separating seedlings. Seven densities were set up using Lannen 308 Japanese Paper Pots (cell volume $65 \mathrm{~cm}^{3}$ ). This system is used to produce commercial crops of Corsican pine scedlings in the United Kingdom; however, for this experiment the cells were lined with thin plastic sheeting to prevent lateral movement of roots or nutrients and water between adjacent cells. The remain- ing three densities used wider diameter plastic tubes filled with the same volume of media as used in the paper pot cells, arranged in an hexagonal pattern. Cultural details for growing the seedlings were similar to those described in the first experiment.

Twenty seedlings were harvested from the centre of each plot during the following winter and the shoot height, root collar diameter and shoot and root dry weight were measured for each seedling. The variance in height, root collar diameter and dry weight tended to increase with mean plant size; thus, their relationships with density were analyzed by fitting generalized linear models to the reciprocal of the measured parameters using gamma error distribution $[3,5]$. The models were fitted using procedures in Genstat [13]. Results are presented as scatter plots and curves of observed and fitted values respectively. The fitted equations are summarized in table $I I$.

\subsection{Experiment 3}

Douglas-fir seedlings of coastal Washington origin were sown in April at five seedling densities ranging from over 1500 to about $100 \mathrm{~m}^{-2}$ in Lannen 308 Ecopots. Each density was replicated four times and the trays were arranged in a randomized block design in a ventilated polythene tunnel. In mid-November, five seedlings were randomly selected from the centre of each tray and shoot height, root collar diameter, shoot and root dry weight were measured on cach seedling. Relationships between these parameters and density were again analyzed using generalized linear models and the results are plotted on the same axes as the results from experiment 2.

Differences in light interception by the canopy of seedlings grown at different densities were followed throughout the summer by measuring the percentage of the above-canopy photosynthetically active radiation, which was transmitted to the media surface using quantum sensors (SKP 200 Skye Instruments Ltd Llandrind-Wells, UK).

\subsection{Experiment 4}

The effects of cell volume and seedling density on the growth of Douglas-fir seedlings was 
Table II. Estimated coefficients from inverse linear models for size variables of Corsican pine, Scots pine (experiment 2) and Douglas-fir (experiment 3) fitted against seedling density.

\begin{tabular}{|c|c|c|c|c|c|}
\hline Species & $\begin{array}{l}\text { Variate } \\
(y)^{1}\end{array}$ & $\begin{array}{c}\text { Constant } \\
\text { (a) }{ }^{1}\end{array}$ & $\begin{array}{l}\text { Coefficient of } \\
\text { density (b) }\end{array}$ & $\begin{array}{l}\% \text { total } \\
\text { deviance }\end{array}$ & $\begin{array}{l}\text { Significance of } \\
\text { deviance ratio }\end{array}$ \\
\hline Corsican pine & $\begin{array}{l}\text { Shoot height }(\mathrm{cm}) \\
\text { Root collar diameter }(\mathrm{mm}) \\
\text { Shoot dry weight }(\mathrm{g}) \\
\text { Root dry weight }(\mathrm{g})\end{array}$ & $\begin{array}{l}0.1465 \\
0.3386 \\
0.6356 \\
0.8286\end{array}$ & $\begin{array}{l}-6.274 \times 10^{-5} \\
2.205 \times 10^{-4} \\
5.770 \times 10^{-4} \\
1.816 \times 10^{-3}\end{array}$ & $\begin{array}{l}85.4 \\
90.6 \\
75.8 \\
95.2\end{array}$ & $\begin{array}{l}* * * \\
* * * \\
* * * \\
* * *\end{array}$ \\
\hline Scots pine & $\begin{array}{l}\text { Shoot height }(\mathrm{cm}) \\
\text { Root collar diameter }(\mathrm{mm}) \\
\text { Shoot dry weight }(\mathrm{g}) \\
\text { Root dry weight }(\mathrm{g})\end{array}$ & $\begin{array}{l}0.0822 \\
0.3154 \\
0.5464 \\
0.5836\end{array}$ & $\begin{array}{l}-2.196 \times 10^{-5} \\
1.605 \times 10^{-4} \\
7.580 \times 10^{-4} \\
1.646 \times 10^{-3}\end{array}$ & $\begin{array}{l}45.2 \\
61.6 \\
79.1 \\
94.7\end{array}$ & $\begin{array}{l}* * \\
* * \\
* * * \\
* * *\end{array}$ \\
\hline Douglas-fir & $\begin{array}{l}\text { Shoot height }(\mathrm{cm}) \\
\text { Root collar diameter }(\mathrm{mm}) \\
\text { Shoot dry weight }(\mathrm{g}) \\
\text { Root dry weight }(\mathrm{g})\end{array}$ & $\begin{array}{l}\overline{0.3914} \\
0.5604 \\
1.1769\end{array}$ & $\begin{array}{r}-173 \times 10^{-4} \\
9.540 \times 10^{-4} \\
1.914 \times 10^{-4}\end{array}$ & $\begin{array}{l}-\overline{99.7} \\
95.3 \\
98.8\end{array}$ & $\begin{array}{l}\text { n.s. } \\
* * * \\
* * * \\
* * *\end{array}$ \\
\hline
\end{tabular}

${ }^{1}$ The fitted models are of the form $1 / \mathrm{y}=\mathrm{a}+\mathrm{bx} . \mathrm{n} . \mathrm{s} .$, not significant; $* * P<0.01 ; * * * P<0.001$.

Table III. Container dimensions and growing densities used for raising Douglas-fir seedlings in experiment 4 .

\begin{tabular}{|c|c|c|c|c|c|c|}
\hline \multirow{2}{*}{$\begin{array}{l}\text { Container } \\
\text { design }\end{array}$} & \multirow{2}{*}{$\begin{array}{l}\text { Diameter } \\
\quad(\mathrm{cm})\end{array}$} & \multirow{2}{*}{$\begin{array}{l}\text { Depth } \\
(\mathrm{cm})\end{array}$} & \multirow{2}{*}{$\begin{array}{l}\text { Volume } \\
\left(\mathrm{cm}^{3}\right)\end{array}$} & \multicolumn{3}{|c|}{ Density $\left(\mathrm{m}^{-2}\right)$} \\
\hline & & & & D1 & D2 & D3 \\
\hline 308 & 3.0 & 7.5 & 53 & 108 & 179 & 392 \\
\hline 315 & 3.0 & 15.0 & 106 & 108 & 179 & 392 \\
\hline 608 & 5.6 & 7.5 & 185 & 112 & 208 & 433 \\
\hline 615 & 5.6 & 15.0 & 369 & 112 & 208 & 433 \\
\hline
\end{tabular}

investigated by using four cell volumes resulting from the factorial combination of two widths $(3$ and $5.6 \mathrm{~cm}$ ) combined with two depths $(7.5$ and $15 \mathrm{~cm})$ of Lannen Ecopots. The manufacturer specifies cell size as a three digit code consisting of the nominal width (first number) and depth (last two numbers). Thus, the four sizes used in this experiment were $308,315,608$ and 615 . Trays of each cell size were sown in April at approximately the same three densities (table III). All treatments were replicated four times and arranged in a randomized block design on benches in a polythene tunnel. Trays with $5.6-\mathrm{cm}$ deep cells were placed on supports to raise the top surface to the same height as the $15-\mathrm{cm}$ deep cells. Cultural conditions and measurements were the same as described in the third experiment and the results were analyzed by ANOVA.

\subsection{Experiment 5}

The field performance of Douglas-fir plants from the five container densities in experiment 3 were tested in an outplanting experiment. The experiment was planted on a podzolic brown earth at $200 \mathrm{~m}$ a.s.l. in Monaughty Forest, Grampian Region, Scotland (Iatitude $57^{\circ} 30^{\circ} \mathrm{N}$ ) in April 1991. The location has an 
annual rainfall of $850 \mathrm{~mm}$ and between 1000 and 1375 day-degrees above $5.6^{\circ} \mathrm{C}$. The site had been clear-felled in spring 1990 and cultivated with a double mouldboard plough in the following September. Trees were sprayed with permethrin against Hylobius attack in May and August 1991, April and September 1992 and April 1993. Competing vegetation, predominantly bracken (Pteridium aquilinum (L.) Kuhn), was cut back by hand in summer 1991 and 1992.

Plants from the five container densities (i.e. $100,180,390,780$ and $1550 \mathrm{~m}^{-2}$ ) were planted in a randomized block design with four replicates. Plants chosen for the field experiment were selected at random from the density treatments with no culling for size or form. In addition, plots of 2-ycar-old undercut seedlings of another coastal provenance were included for comparison with the container seedlings. A 20-plant plot was used for all treatments except the $100 \mathrm{~m}^{-2}$ density where 16 plants were used. Survival, seedling height and root collar diameter were assessed at planting and at the end of the first and third growing seasons. Data were statistically analyzed by ANOVA. Percentages were arcsine transformed before analysis; however, non-transformed percentages are presented for clarity.

\section{RESULTS}

\subsection{Experiment 1}

Seedling density had a highly significant effect on both the shoot height and the root collar diameter of Corsican pine seedlings (table IV). Shoot height showed a positive linear relationship with density $(P<0.001)$, increasing from about $5 \mathrm{~cm}$ at the lowest density to nearly $12 \mathrm{~cm}$ at full stocking. In contrast, root collar diameter showed a significant negative relationship with seedling density $(P<0.001)$, falling by about one quarter from $2.2 \mathrm{~mm}$ in seedlings grown at $192 \mathrm{~m}^{-2}$ to $1.7 \mathrm{~mm}$ at $1525 \mathrm{~m}^{-2}$.

\subsection{Experiment 2}

Corsican pine seedlings again showed a significant positive relationship between height and density (figure la). Seedlings were on average only $7 \mathrm{~cm}$ tall at the lowest density $\left(107 \mathrm{~m}^{-2}\right)$, but grew to just over $12 \mathrm{~cm}$ at the highest density - an increase of nearly $70 \%$. On average, Scots pine seedlings were about $50 \%$ taller than Corsican pine seedlings and height increased from 12 to $17 \mathrm{~cm}$ across the range of densities. However, the relationship between height and density was weaker than for Corsican pine (table II) with evidence of systematic variation with density ( $f$ igure (a).

Root collar diameters of both species were negatively related to seedling density (figure $1 b$ ) and the relationship was again weaker for Scots pine than for Cor-

Table IV. The effects of growing density on the height and root collar diameter of Corsican pine seedlings in experiment 1 .

\begin{tabular}{lcc}
\hline $\begin{array}{l}\text { Density } \\
\left(\text { plants } \mathrm{m}^{-2}\right)\end{array}$ & $\begin{array}{c}\text { Shoot height } \\
(\mathrm{cm})\end{array}$ & $\begin{array}{c}\text { Root collar diameter } \\
(\mathrm{mm})\end{array}$ \\
\hline 192 & 5.2 & 2.21 \\
384 & 5.9 & 2.03 \\
1030 & 9.2 & 1.81 \\
1525 & 11.7 & 1.70 \\
SED & 0.93 & 0.111
\end{tabular}

SED, standard error of differences between means. 

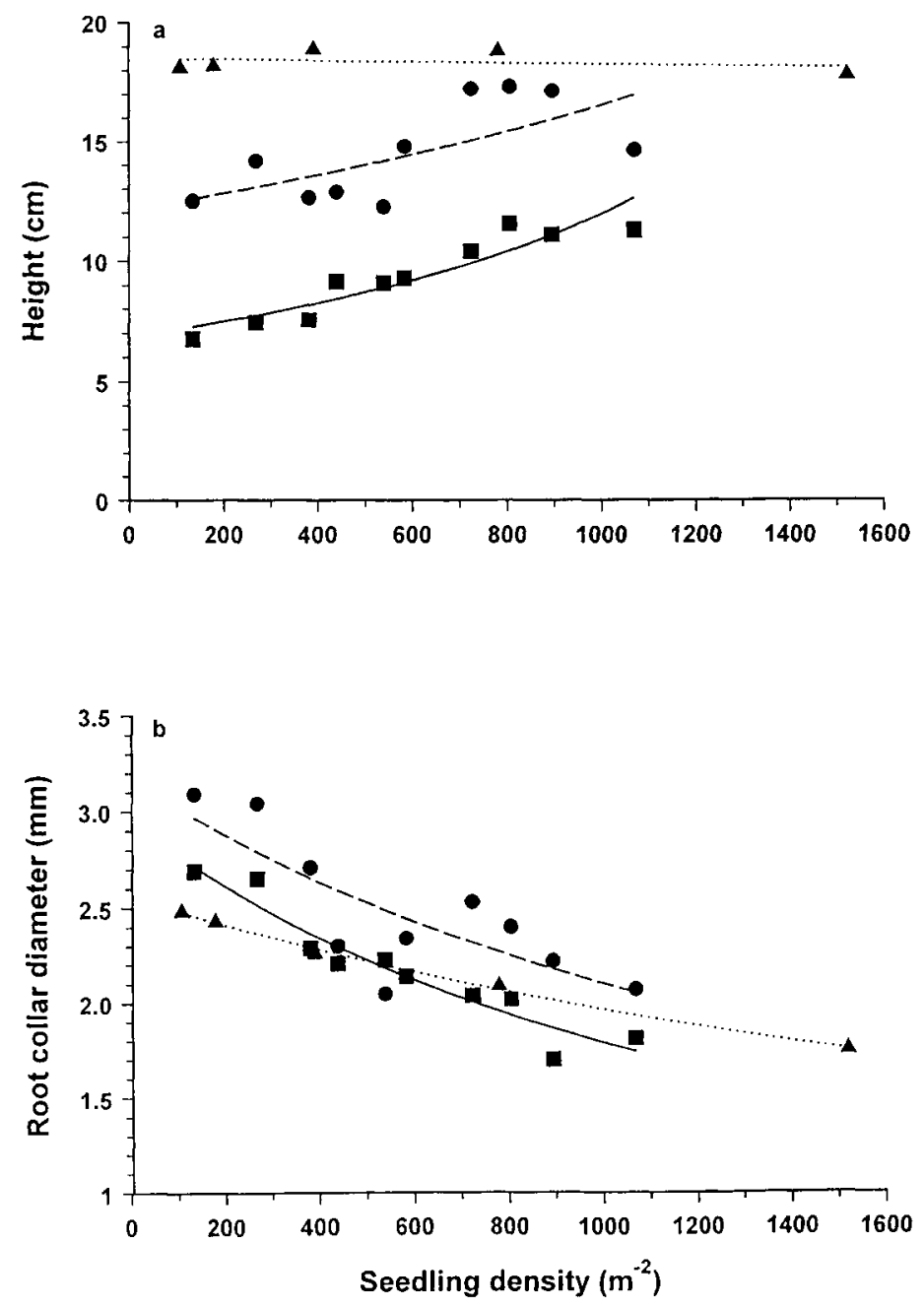

Figure 1. The effect of growing density on (a) seedling height and (b) root collar diameter of (- - ) Corsican pine, (---) Scots pine and (.. $\boldsymbol{\Delta}^{-\cdot)}$ Douglas-fir seedlings. Parameters for fitted curves are shown in table $I I$.

sican pine (table II). Stem diameters for Scots pine averaged $3 \mathrm{~mm}$ at 107 seedlings $\mathrm{m}^{-2}$ and declined to $2.1 \mathrm{~mm}$ at the closest spacing. Corsican pine showed a highly significant negative effect of growing density on root collar diameters, declining from $2.7 \mathrm{~mm}$ at the widest spacing to $1.7 \mathrm{~mm}$ at the closest spacing.
The relationship between total dry matter production per tray (biomass) and seedling density was positive and nearly identical in both species (figure 2a). The relationship was non-linear with about $78 \%$ of the total increase occurring when density was increased from 134 to $584 \mathrm{~m}^{-2}$. At higher growing densities, the 

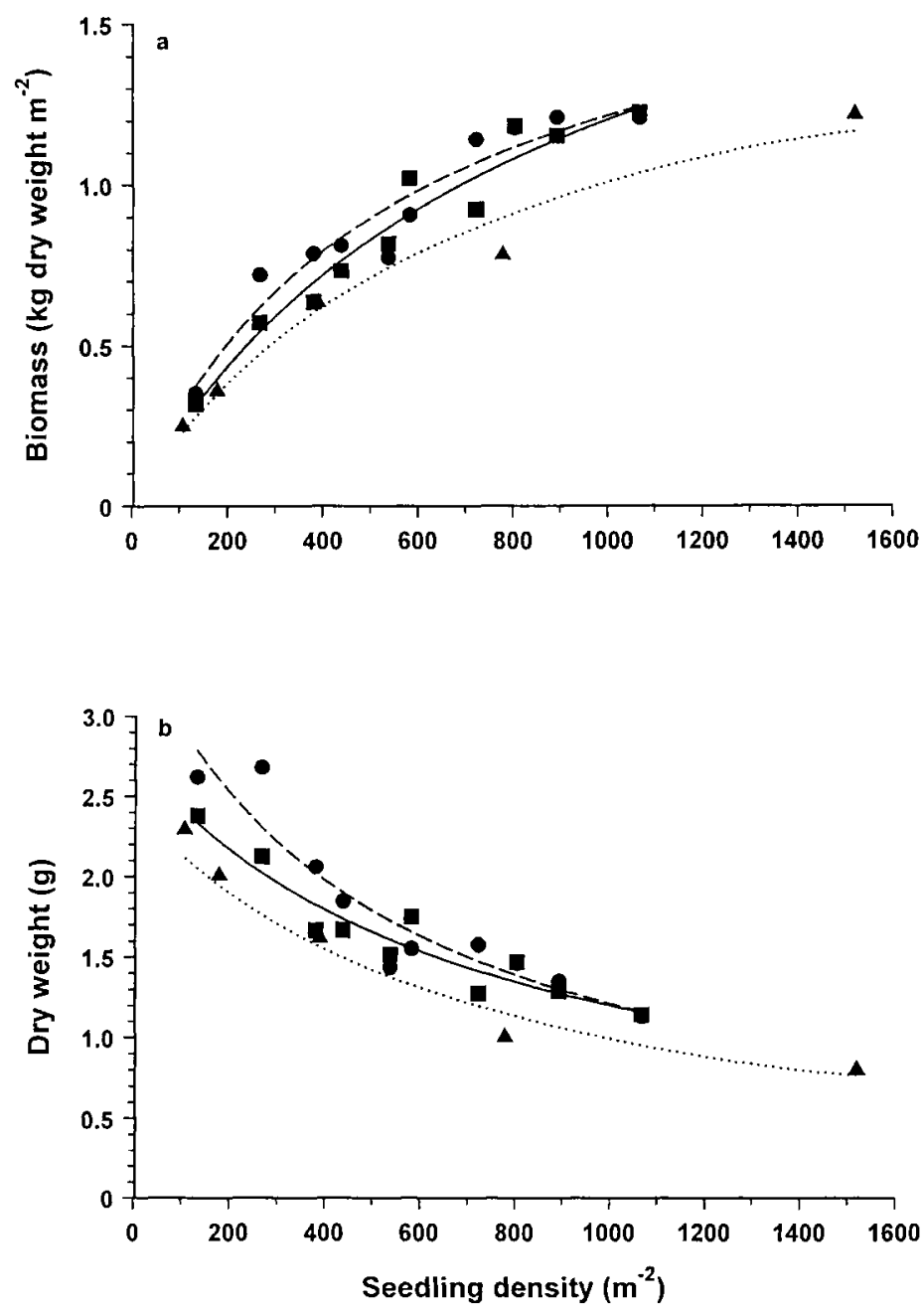

Figure 2. The effect of seedling density on (a) seedling biomass production and (b) total seedling dry weight of $(-\mathbf{-})$ Corsican pine, (-- --) Scots pine and (.. $\left.\boldsymbol{A}^{-\cdot}\right)$ Douglas-fir seedlings. Parameters for fitted curves of total weight are shown in table II. The curve for biomass is derived from fitted values of total weight.

rate of increase in biomass decreased. In contrast, the dry weight of individual seedlings decreased with growing density (figure $2 b$ ). Seedlings of both species grown at the closest spacing were about half the weight of those raised at the widest spacing, and again about $70 \%$ of the decrease in weight had occurred as den- sity was increased to $584 \mathrm{~m}^{-2}$. The relationship between shoot dry weight and density was the same for both pines and followed a similar pattern to the trend for total seedling dry weight (figure $3 a$ ); shoot weight was halved across the density range, and the majority of the weight loss $(70 \%)$ had occurred at $584 \mathrm{~m}^{-2}$. 

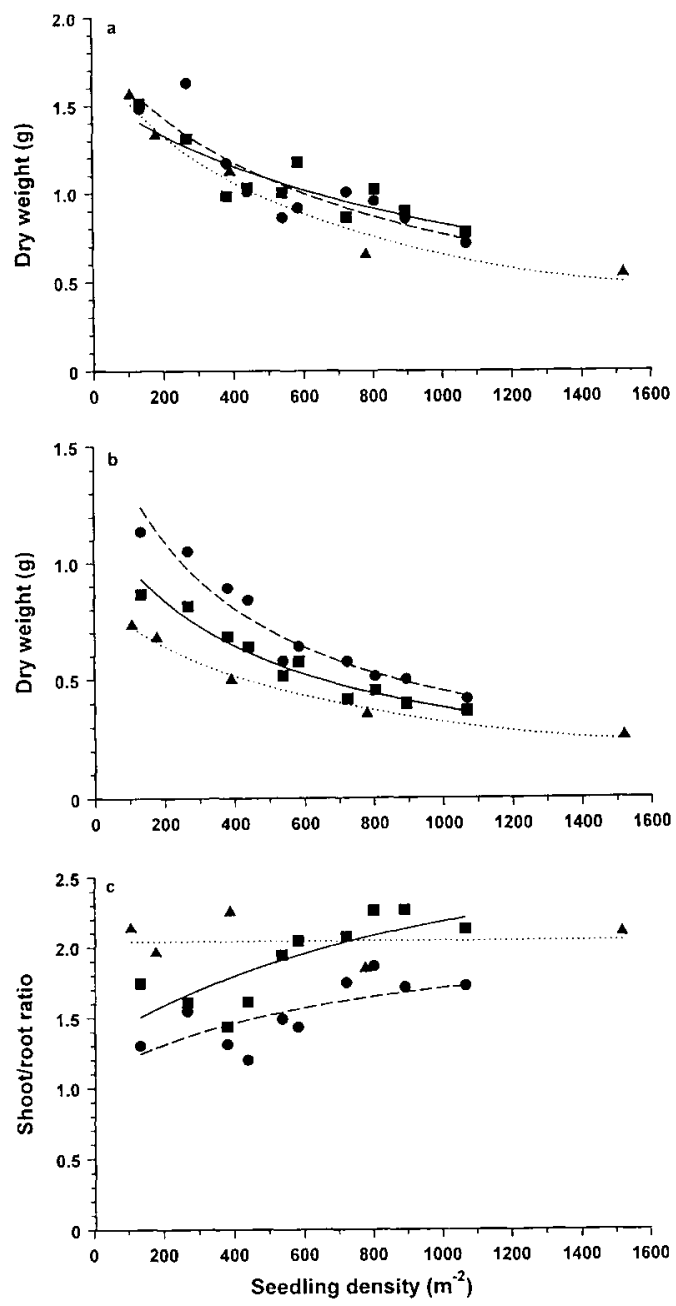

Figure 3. The effect of seedling density on (a) shoot dry weight, (b) root dry weight and (c) shoot/root ratio of (--) Corsican pine, (-- --) Scots pine and (.....) Douglas-fir seedlings. Parameters for fitted curves of shoot and root dry weight are shown in table II. The curve for shoot/root ratio is derived from fitted values of shoot and root dry weight.

Growing density had the largest effect on the weight of the root systems of both species (figure $3 b$, table II). The roots of seedlings grown at the highest density were only about one third the weight of those grown at the widest spacing, and again more than $70 \%$ of this reduction took place as density was increased to
$584 \mathrm{~m}^{-2}$. Unlike shoot weight, the roots of Scots pine were heavier than Corsican pine (figure $3 b$ ). The larger reduction in root dry weight compared with shoot weight resulted from a decrease in the allocation of dry matter to root system as density was increased (figure 3c). 
The height of Corsican pine seedlings was negatively correlated with both shoot and root dry weight, but there was no correlation between the height and weight of Scots pine seedling (table $V$ ). There was a strong positive correlation in both species between root collar diameter and the weight of both shoots and roots.

\subsection{Experiment 3}

The response of Douglas-fir seedlings to being grown at different densities was generally similar to the results of the previous experiment (figures 1-3). However, seedling height was unaffected by density (figure 1 a). Both biomass production and total dry weight were about $20 \%$ lower in Douglas-fir seedlings than with the pines (figure 2). Shoot dry weight was very similar for all three species across the range of densities (figure $3 a$ ), whereas Douglas-fir had the lowest root dry weight (figure $3 b$ ). Unlike the pines, there was no effect of growing density on the parti- tioning of dry matter between shoot and root (figure $3 \mathrm{c}$ ).

The percentage of incident light transmitted to the surface of the trays depended on the growing density (figure 4). The amount of light transmitted through seedlings grown at the widest spacing was between 70 to $80 \%$ throughout the summer. At intermediate densities of 179 and $372 \mathrm{~m}^{-2}$ the percentage transmission decreased from about 65 to $50 \%$ after 14 weeks from sowing. At $780 \mathrm{~m}^{-2}$ transmission had declined to only $10 \%$ after 16 weeks, while all of the light was intercepted at the highest density after 14 weeks.

\subsection{Experiment 4}

The effects of changes in cell dimensions on seedling growth depended on growing density (figure 5). At the highest density (D3, $400 \mathrm{~m}^{-2}$ ), there was no statistically significant difference in shoot and root dry weight, and stem diameter

Table V. Correlation coefficients of height and root collar diameter with shoot, root and seedling dry weight of Corsican pine, Scots pine and Douglas-fir seedlings.

\begin{tabular}{lll}
\hline & Height & Root collar diameter \\
\hline Corsican pine & & $0.871^{* *}$ \\
$\quad$ Shoot dry weight & $-0.759^{*}$ & $0.951^{* * *}$ \\
Root dry weight & $-0.925^{* * *}$ & $0.932^{* * *}$ \\
$\quad$ Total dry weight & $-0.856^{* * *}$ & \\
Scots pine & & $0.957^{* * *}$ \\
$\quad$ Shoot dry weight & $-0.334 \mathrm{~ns}$ & $0.873^{* * *}$ \\
Root dry weight & $-0.601 \mathrm{~ns}$ & $0.938^{* * *}$ \\
Total dry weight & $-0.467 \mathrm{~ns}$ & $0.934^{* * *}$ \\
Douglas-fir & & $0.924^{* * *}$ \\
$\quad$ Shoot dry weight & $-0.013 \mathrm{~ns}$ & $0.934^{* * *}$ \\
$\quad$ Root dry weight & $-0.026 \mathrm{~ns}$ & \\
Total dry weight & $-0.017 \mathrm{~ns}$ & \\
\hline
\end{tabular}

$\mathrm{ns}$, not significant; $* P<0.05 ; * * P<0.01 ; * * * P<0.001$. 


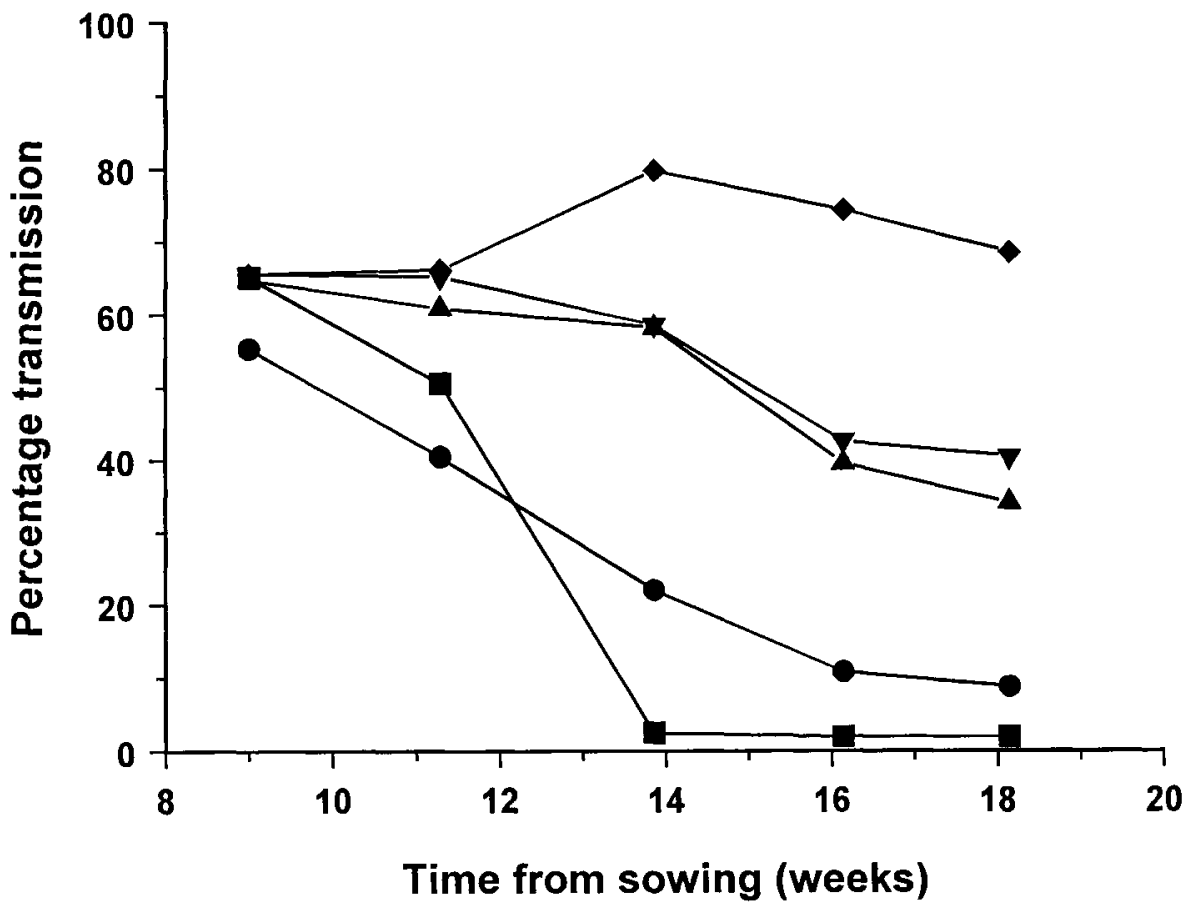

Figure 4. Changes over time in the percentage transmission of light through the canopies of Douglas-fir seedlings grown at densities of: $108, \boldsymbol{\nabla} 179, \boldsymbol{\Delta} 392,780$ and 1522 plants $\mathrm{m}^{-2}$.
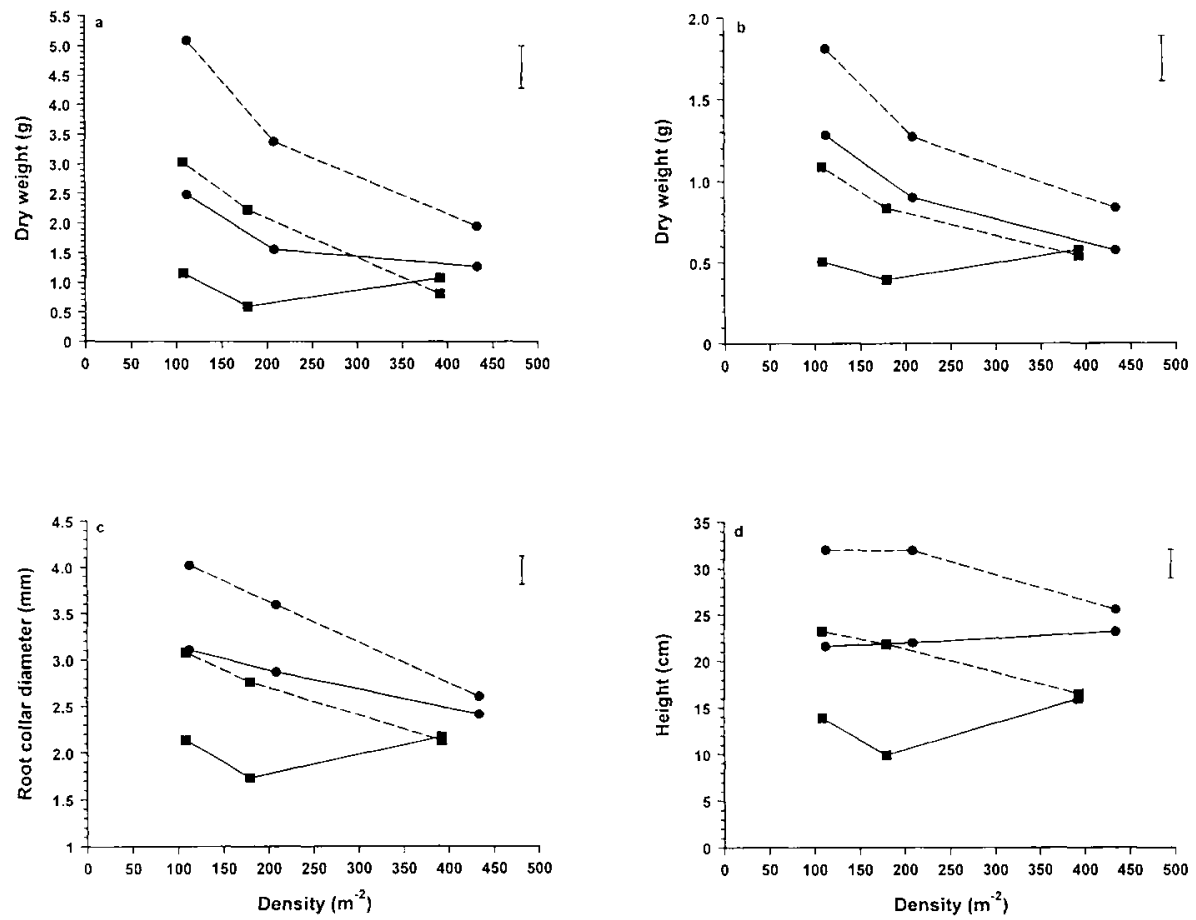

Figure 5. The effects of container size on (a) shoot dry weight, (b) root dry weight, (c) root collar diameter and (d) shoot height of Douglas-fir seedlings grown at three densities. Container sizes used were Lannen 308, 315, 608 and 615 Ecopots. Actual dimensions were: width $\mathbf{\square} 3.0 \mathrm{~cm}$, - $5.6 \mathrm{~cm}$; depth $-7.5 \mathrm{~cm},--15 \mathrm{~cm}$. Standard errors of difference are shown as vertical bars. 
between seedlings grown in any of the four container sizes. As density was decreased, the weight and root collar diameter of seedlings grown in the smallest volume containers (308) remained unchanged, but seedling size increased in the other larger three container sizes. At the lowest density, seedlings grown in 615 containers were four times heavier than those grown in 308 containers, and were more than twice the size of seedlings raised in the same size container at $400 \mathrm{~m}^{-2}$ (figures $5 a$ and $b$ ). Root collar diameter showed a similar response to the increases in cell size and growing density as dry weight (figure $5 c$ ). Although seedling height increased with cell size, it tended not to respond to changes in density within any particular container size (figure $5 d$ ). The increased growth in larger containers at low densities did not appear to be related just to increasing cell volume, since growth in 315 and 608 cells was generally similar despite the fact that their respective volumes were 106 and $185 \mathrm{~cm}^{3}$ respectively.

\subsection{Experiment 5}

An average of $86 \%$ of the Douglas-fir seedlings raised at densities between 100 and $780 \mathrm{~m}^{-2}$ survived by the end of the first growing season after planting in the forest (figure $6 a$ ). but survival was significantly reduced to $54 \%$ in plants raised at the highest density $\left(1550 \mathrm{~m}^{-2}\right)$. Subsequent losses over the next 2 years were the same for each treatment and averaged about $7 \%$ by the end of the third growing season. There was a high Hylobius population during the first two seasons, which was responsible for some of the losses.

By the end of the third year after planting, plants raised at $780 \mathrm{~m}^{-2}$ were the tallest at just over $100 \mathrm{~cm}$, whilst seedlings grown at the lowest as well as the high- est densities were just significantly shorter at 88 and $76 \mathrm{~cm}$, respectively (figure 6 b). Plants raised at 390 and $780 \mathrm{~m}^{-2}$ produced the greatest height increment $(13.6 \mathrm{~cm})$ during the first year after planting. This was significantly higher than in seedlings that had been raised at both lower and higher densities $(5.7$ and $8.9 \mathrm{~cm}$, respectively). Height increments were similar at an average of $68 \mathrm{~cm}$ over the following 2 years for all densities except the highest where the increment was significantly less at $56 \mathrm{~cm}$.

A very similar pattern occurred with the increase in root collar diameter between seedlings raised at different densities (figure $6 c$ ). The greatest increments in root collar diameter occurred at intermediate densities. This resulted in the negative relation between diameter and density which existed at planting, changing to a distribution with a distinct optimum at $780 \mathrm{~m}^{-2}$ where stem diameter peaked at $19 \mathrm{~mm}$ and fell to 16 and $13 \mathrm{~mm}$ at the lowest and highest densities.

Survival of the undercut bare-root seedlings was similar to the survival of container seedlings grown at densities below $1550 \mathrm{~m}^{-2}$ (figure $6 \mathrm{a}$ ), but the pattern of height and stem diameter growth was different. At planting, the undercut seedlings were nearly twice as tall and thick as the container seedlings. However, increases in height and diameter were negligible during the first year after planting, and over the next 2 years these increments were only about the same as for the smallest seedlings that had been grown at the highest container density. Consequently, the initial size advantage of the bare-root seedlings had disappeared by the end of the third year.

\section{DISCUSSION}

The results of the first three experiments showed that growing density, with 

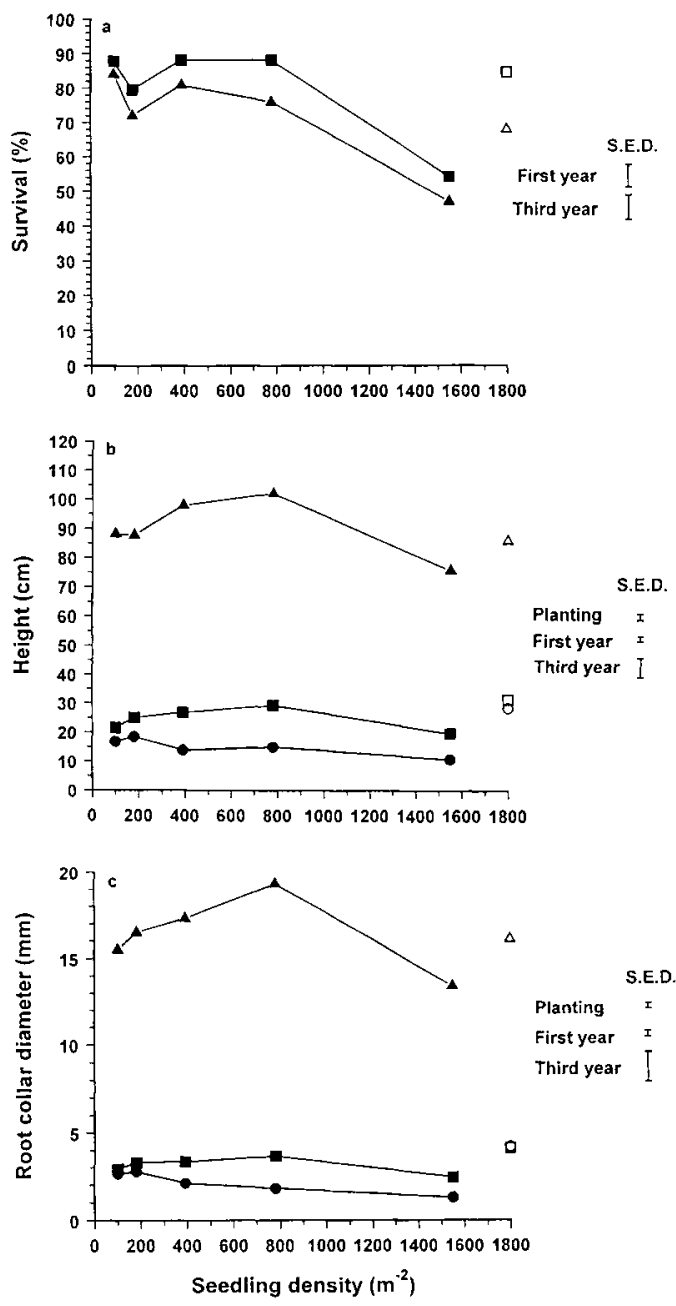

Figure 6. The effects of seedling density on (a) survival, (b) seedling height and c) root collar diameter of Douglas-fir seedlings $(\mathbf{O})$ at planting, $(\boldsymbol{\square})$ after 1 year and $(\boldsymbol{\Delta})$ after 3 years. Open symbols refer to measurements made on 2-year-old undercut seedlings. Standard errors of difference (S.E.D.) are shown as vertical bars.

rooting volume held constant, has a strong influence on the growth and development of Corsican pine, Scots pine and Douglas-fir. The relationship between production of biomass, total and shoot dry weight with density was very similar in all three species. In addition, all three species showed a similar negative response to density for root dry weight and root collar diameter, although individual species differed in the relative size of these parameters. The response of seedling height was much more variable between the three conifers. The height of Douglas-fir 
seedlings was unaffected by growing density, while the two pine species showed a positive response to growing density with the tallest seedlings being produced at the highest density. In this study, the height of Corsican pine seedlings was particularly strongly affected by growing density, suggesting that density effects are in part responsible for the uneven distribution of seedling heights between the centre and edges of trays and benches during commercial production.

The reductions in seedling dry weight and root collar diameter with increasing density found in these three species are similar to those reported in other studies using container seedlings where the effects of density alone have been investigated $[1,14,16]$. The differences between Douglas-fir and the two pines in the effects of growing density on seedling height are also apparent in other studies on both these and other species. The positive relationship between seedling height and density found in Cosican and Scots pine has been reported in interior spruce seedlings where shoot length increased by more than $60 \%$ as growing density was increased from 100 to over $1000 \mathrm{~m}^{-2}$ [14]. Hulten [8], however, found that the height of Scots pine seedlings only increased substantially as growing density was increased to 400 plants $\mathrm{m}^{-2}$; at higher densities up to $1200 \mathrm{~m}^{-2}$ height was slightly reduced. In contrast to the lack of response of the height of Douglas-fir seedlings to density found in this study, Timmis and Tanaka [16] reported that seedlings were significantly taller when grown at a high density of 1080 plants $\mathrm{m}^{-2}$; however, at lower densities ( 270 and $810 \mathrm{~m}^{-2}$ ) there were only small although statistically significant differences in height. Loblolly pine grown over a wide range of densities (452 to 1808 plants $\mathrm{m}^{-2}$ ) showed a similar response to Douglas-fir in this study with no simple relationship at all between height and density [1]. The basis for these differences between species in the way shoot elongation responds to density warrants further investigation.

Since the root systems of individual seedlings were isolated from each other, the effects of density on the growth of these seedlings were caused by the effects of mutual shading on the interception of light by seedlings and on changes in associated environmental factors, such as temperature, within the seedlings. Reciprocal equations have been widely used to describe relationships between mean plant size and density [5]. The close relationships obtained between the reciprocals of mean seedling weights and density would be expected if the effects of competition on plant size are due to the partitioning of available growing space between individual seedlings. In the absence of root competition, the density over which competition intensifies is a function of the size and geometry of the seedling canopy in relation to the space available. The relationship between area and density is nonlinear with the area available per seedling increasing substantially at densities less than about $500 \mathrm{~m}^{-2}$ (figure 7), corresponding to the density range where the majority of the increases in root and shoot dry weight occurred in these experiments.

At densities above $400 \mathrm{~m}^{-2}$ the canopy of Douglas-fir seedlings intercepted nearly all of the incident radiation. At wider spacings, more light is utilized by individual seedlings since fewer of their needles would have been below the light compensation point. Also in Douglas-fir, Timmis and Tanaka [16] estimated that ten times as much visible radiation reached the lower needles of wider-spaced seedlings; the greater light interception at low densities resulted in an increase in dry matter production by individual seedlings as well as an increased allocation of carbon for root growth. At wider spacings the increased absorption of radiation at the compost surface resulted in warmer stem 


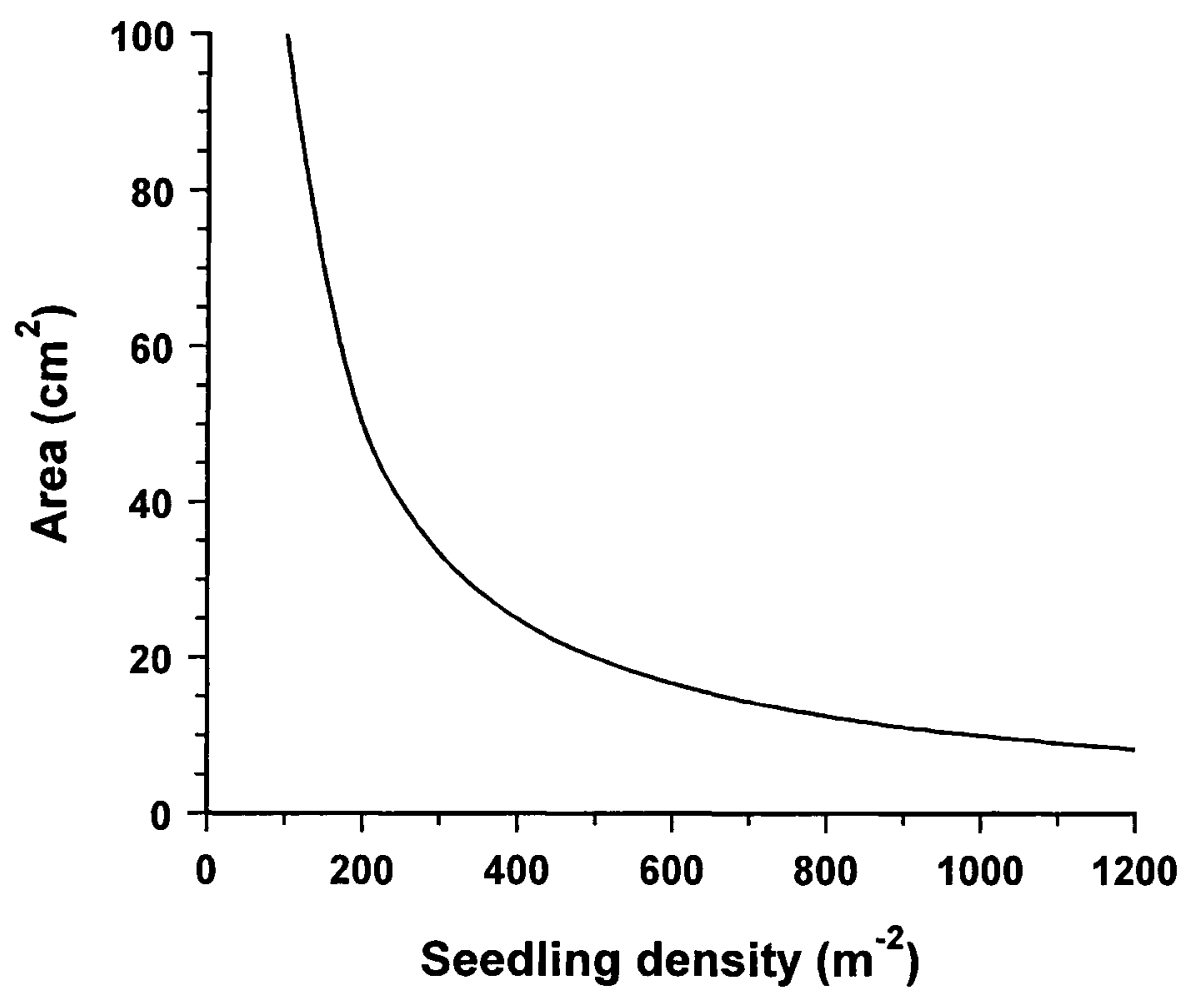

Figure 7. A graph of the relationship between the area available per seedling and density.

temperatures [16], warmer root temperatures and possibly drier growing media than at closer spacings. Changes in leaf area and leaf-air vapour pressure difference would also affect water use by seedlings at different densities. Close spacing will also modify the quality of light beneath the canopy, especially the red:far red ratio, and this probably has an important role in increasing the extension growth of seedlings at high density $[12,17]$.

The interaction between container density and volume found in experiment 4 suggests that at high seedling densities, intense competition for light is the limiting factor affecting seedling size. The weight of Douglas-fir seedlings grown at $400 \mathrm{~m}^{-2}$ did not increase when container volume was increased; increasing the volume of the containers was only effective at increasing seedling size at lower growing densities. Thus, when shoot competition was less intense at wider spacings, container volume then became the limiting factor for seedling growth.

Morphological features of seedlings like height and diameter are frequently used to grade seedling stock. Root collar diameter is considered to be a better predictor of outplanting performance than shoot height since it is often correlated with seedling weight and the size of the root system [11]. Growing density produced strong positive correlations between root collar diameter and shoot and root weight in all three species, whereas plant height was either negatively correlated with weight in Corsican pine, or was not 
significantly correlated in Scots pine and Douglas-fir. Specification of seedling size in terms of shoot height alone is not a good measure of seedling size since height growth of container seedlings grown at close spacing is a response to mutual shading, rather than to an increase in dry matter accumulation by seedlings; root collar diameter is a more useful indicator of seedling size.

Taller seedlings generally remain taller in the years following outplanting (e.g. [14]). The results of the outplanting experiment with Douglas-fir showed that the smallest seedlings, which were raised at the highest density, had significantly poorer survival, presumably because their smaller root collar diameter and lesser root volume made them more vulnerable to site-induced stresses after planting such as weed competition and shoot damage by the large pine weevil Hylobius abietis. However, subsequent growth did not show a simple relationship with initial size, since the greatest growth occurred in plants raised at intermediate densities of around $800 \mathrm{~m}^{-2}$, with the larger plants that had been raised at lower container densities growing significantly less. Indeed, the increment of the plants from the widest treatments was not significantly greater than that of the plants grown at the closest spacings. It is not clear why this variation in growth response with growing density should have occurred. The better-thanexpected growth of the seedlings grown at the closest density could be due to initial mortality occurring amongst the smallest and most vulnerable seedlings in this treatment, leaving only the better quality plants to grow on. Reasons for the poorerthan-expected performance of the plants grown at the widest spacing are less evident. However, similar results were reported by Deans et al. [4] and Mason et al. [10] in bare-root Douglas-fir. In these studies plants were produced over 2 years at four densities from 286 to 74 plants $\mathrm{m}^{-2}$.
Height growth in the nursery was unaffected by spacing, but root collar diameter, root and shoot dry weight all increased at wider spacings. However, 2 years after outplanting, survival and height growth of plants raised at an intermediate density of $150 \mathrm{~m}^{-2}$ was better than those grown at wider or closer spacings. One may speculate that there could be an interaction between spacing and physiological condition such as the number of bud initials, which affects outplanting growth and warrants further investigation.

All three species in this investigation are often produced in British nurseries at densities ranging from 800 to $1200 \mathrm{~m}^{-2}$. Good survival and growth of these seedlings can be achieved after outplanting on suitable sites given adequate ground preparation and proper weed control and protection. There may be instances, such as planting on a weedy and/or uncultivated site, where a larger specification seedling may prove advantageous. To obtain substantially heavier plants, the results of this study suggest that seedlings would have to be grown at densities below $400 \mathrm{~m}^{-2}$ in larger volume cells to reduce competition for light and to allow seedlings to respond to increased availability of mineral nutrients and water. In practice, seedling density and cell volume are interrelated since selecting a larger container size results in both an increase in volume and a decrease in seedling density. However, there has to be a compromise between selecting a growing density that will produce seedlings of the desired specification, against the financial constraint of reducing the yield of seedlings that can be grown on a given area of a tunnel or glasshouse.

\section{ACKNOWLEDGEMENTS}

We thank the staff of the nurseries at Alice Holt Lodge and the Northern Research Station for raising the container seedlings, and the staff 
of the Newton field station for planting and maintaining the field experiment. Ian Wright and Andrew Peace helped with the statistical analysis, and John Morgan commented on the draft text.

\section{REFERENCES}

[1] Barnett J.P., Brissette J.C., Producing southern pine seedlings in containers, Gen. Tech. Rep. SO-59 (1986) USDA Forest Service, Southern Experiment Station, New Orleans, LA, 71 p.

[2] Carlson L.W., Endean F., The effect of rooting volume and container configuration on the early growth of white spruce seedlings, Can. J. For. Res. 6 (1976) 22 l-224.

[3] Crawley M.J., GLIM for Ecologists, Blackwell Scientific Publications, Oxford, 1993.

[4] Deans J.D., Mason W.L., Cannell M.G.R., Sharpe A.L., Sheppard L.J., Growing regimes for bare-root stock of Sitka spruce, Douglas-fir and Scots pine. I. Morphology at the end of the nursery phase, in: Mason W.L., Deans J.D., Thompson S. (Eds.), Producing Uniform Conifer Planting Stock, Forestry Suppl. 62, 1989, pp. 275-284.

[5] Drew T.J., Flewelling J.W., Some recent Japanese theories of yield-density relationships and their application to Monterey pine plantations, For. Sci. 23 (1977) 517-534.

[6] Endean F., Carlson L.W., The effect of rooting volume on the early growth of lodgepole pine seedlings, Can. J. For. Res. 5 (1975) $55-60$.

[7] Hocking D., Mitchell D.L., The influences of rooting volume - seedling espacement and substratum density on greenhouse growth of lodgepole pine, white spruce, and Douglas-fir grown in extruded peat cylinders, Can. J. For. Res. 5 (1975) 440-451.

[8] Hulten H., Current levels of planting stock uniformity and grading - a Scandinavian view, in: Mason W.L., Deans J.D., Thompson S. (Eds.),
Producing Uniform Conifer Planting Stock, Forestry Suppl. 62, 1989, pp. 1-12.

[9] Landis T.D., Containers: types and functions, in: Landis T.D., Tinus R.W., McDonald S.E., Barnett J.P. (Eds.), The Container Tree Nursery Manual, vol. 2, Agricultural Handbook. 674. U.S. Department of Agriculture, Forest Service, Washington, DC, 1990, pp. 1-39.

[10] Mason W.L., Sharpe A.L., Deans J.D., Growing regimes for bare-root stock of Sitka spruce, Douglas-fir and Scots pine. II. Forest performance, in: Mason W.L., Deans J.D., Thompson S. (Eds.), Producing Uniform Conifer Planting Stock, Forestry Suppl. 62, 1989, pp. 275-284.

[11] Mexal J.G., South D.B., Bareroot seedling culture, in: Duryea M.L., Dougherty P.M. (Eds.), Forest Regeneration Manual, Kluwer Academic Publishers, Netherlands, 1991, pp. 89--115.

[12] Morgan D.C., Rook D.A., Warrington I.J., Turnbull H.L., Growth and development of Pinus radiata D. Don: the effect of light quality, Plant Cell Environ. 6 (1983) 691-701.

[13] Payne R.W., Lane P.W., Digby P.G.N., Harding S.A., Leech P.K., Morgan G.W., Todd A.D., Thompson R., Tunnicliffe Wilson G., Welham S.J., White R.P., Genstat 5 Release 3 Reference Manual, Clarendon Press, Oxford, 1993.

[14] Simpson D.G., Growing density and container volume affect nursery and field growth of interior spruce seedlings, North J. Appl. For. 8 (1991) 160-165.

[15] Sutherland D.C., Day R.J., Container volume affects survival and growth of white spruce, black spruce, and Jack pine seedlings: a literature review, North J. Appl. For. 5 (1988) 185-189.

[16] Timmis R., Tanaka Y., Effects of container density and plant water stress on growth and cold hardiness of Douglas-fir seedlings, For. Sci. 22 (1976) 167-172.

[17] Warrington I.J., Rook D.A., Morgan D.C., Turnbull H.L., The influence of simulated shadelight and daylight on growth, development and photosynthesis of Pinus radiata, Agathis australis and Dacrydium cupressinum, Plant Cell Environ. 12 (1989) 343-356. 